Published in final edited form as:

Diabetes Metab. 2014 April ; 40(2): 87-94. doi:10.1016/j.diabet.2013.11.003.

\title{
Gastrointestinal changes after bariatric surgery
}

\author{
I. Querciaa ${ }^{a, d}$, R. Dutiaa,d, D.P. Kotlerc,d,f, S. Belsleye,f, and B. Laferrère ${ }^{a, b, d, f,{ }^{*}}$
}

aNew York Obesity Nutrition Research Center, St. Luke's-Roosevelt Hospital Center, Columbia University College of Physicians and Surgeons, 1111, Amsterdam Avenue, 1034 New York, NY 10025, USA

bDivision of Endocrinology, Diabetes and Nutrition, St Luke's-Roosevelt Hospital Center, New York, NY 10025, USA

'Division of Gastroenterology and Liver Disease, St Luke's-Roosevelt Hospital Center, New York, NY 10025, USA

dDepartment of Medicine, St Luke's-Roosevelt Hospital Center, New York, NY 10025, USA

eDepartment of Surgery, St Luke's-Roosevelt Hospital Center, New York, NY 10025, USA

${ }^{f}$ Columbia University College of Physicians and Surgeons, New York, NY 10025, USA

\section{Abstract}

Severe obesity is a preeminent health care problem that impacts overall health and survival. The most effective treatment for severe obesity is bariatric surgery, an intervention that not only maintains long-term weight loss but also is associated with improvement or remission of several comorbidies including type 2 diabetes mellitus. Some weight loss surgeries modify the gastrointestinal anatomy and physiology, including the secretions and actions of gut peptides. This review describes how bariatric surgery alters the patterns of gastrointestinal motility, nutrient digestion and absorption, gut peptide release, bile acids and the gut microflora, and how these changes alter energy homeostasis and glucose metabolism.

\section{Keywords}

Obesity; Bariatric surgery; Gastric bypass; Diabetes; Gut peptides

\section{Introduction}

Obesity prevalence is alarming - recent data indicate that $36 \%$ of United States (US) adults are obese, defined as a body mass index (BMI) of at least $30 \mathrm{~kg} / \mathrm{m}^{2}$. Furthermore, $15 \%$ and $6 \%$ of the US population is further categorized with class 2 and class 3 obesity, with a BMI

\footnotetext{
(C) 2013 Elsevier Masson SAS. All rights reserved.

"Corresponding author. New York Obesity Nutrition Research Center, St. Luke's-Roosevelt Hospital Center, Columbia University College of Physicians and Surgeons, 1111, Amsterdam Avenue, 1034 New York, NY 10025, USA. Tel.: +1 212523 4643; fax: +1 212523 4830. BBL14@ columbia.edu (B. Laferrère).

Disclosure of interest

The authors declare that they have no conflicts of interest concerning this article.
} 
of at least $35 \mathrm{~kg} / \mathrm{m}^{2}$ and $40 \mathrm{~kg} / \mathrm{m}^{2}$, respectively [1]. Obesity is associated with a number of comorbidities including diabetes, heart disease, hypertension, cancer, sleep apnea, osteoarthritis, and others [2]. Lifestyle intervention can be successful short-term, however there is a high rate of recidivism with individuals returning to or exceeding their previous weight [3]. In contrast, bariatric surgery has been shown to successfully maintain weight loss and there is evidence that changes in gut physiology may play an important role. This review examines the changes in different aspects of gut physiology after bariatric surgery, particularly Roux-en-Y gastric bypass (RYGB), including taste, meal pattern and duration, gastric emptying (GE) and intestinal transit time (ITT), gut hormone release, bile acid (BA) metabolism, and microbiota.

\section{Bariatric surgery}

Bariatric surgery is recommended for adults with a BMI of at least $40 \mathrm{~kg} / \mathrm{m}^{2}$, or $35 \mathrm{~kg} / \mathrm{m}^{2}$ with comorbidities [4]. The recent US Food and Drug Administration approval of adjustable gastric banding (LAGB) (i.e. Lap-Band) for obese individuals with a lower BMI ( $\geq 30$ $\mathrm{kg} / \mathrm{m}^{2}$, with existing comorbidities), suggests a trend for expanding its application to patients with a lower BMI [5].

Commonly performed bariatric procedures may be categorized as predominantly restrictive, predominantly malabsorptive, and those that are a combination of both restriction and malabsorption (Fig. 1). However, as reviewed below, the mechanisms of action of the bypass surgeries go well beyond malabsorption.

\subsection{Predominantly restrictive procedures}

Restrictive procedures decrease the functional volume of the stomach. In LAGB, an adjustable silicone band is placed around the upper stomach to reduce the size of the channel between the upper and lower stomach, in an effort to reduce caloric intake [6]. In vertical banded gastroplasty (VBG), a procedure no longer widely performed, part of the stomach is permanently stapled to create a smaller pouch along the lesser curvature of the stomach [6]. Vertical sleeve gastrectomy (SG) is a non-reversible procedure that permanently reduces stomach size via partial gastrectomy that preserves the lesser curvature and pylorus of the stomach. Although SG anatomically appears to be a purely restrictive procedure, its mechanism of action is likely to be much more complex, as it removes some or all of the cells that produce the potent orexigenic hormone ghrelin, and it alters nutrient transit time, which may explain its superior success over the other restrictive procedures [6]. Future research will determine if SG merits a different categorization.

Advancements and ongoing research on restrictive procedures performed endoscopically have the potential to expand the role of the gastroenterologist in the area of bariatric intervention. Endoluminal sleeves and intragastric balloons have demonstrated short-term efficacy in inducing weight loss as well as concurrent resolution or improvement of obesityrelated comorbidities [7]. A newly proposed technique, the laparoscopic fundoplication combined with mediogastric plication, has been reported to offer improvements in gastroesophageal reflux disease with excess weight loss approaching that of RYGB in patients with a BMI of $32-35 \mathrm{~kg} / \mathrm{m}^{2}$ after 1 year, although long-term data is lacking [8]. 


\subsection{Predominantly malabsorptive procedures}

Although the biliopancreatic diversion (BPD), with duodenal switch, has a restrictive component similar to that of SG, it is generally considered a malabsorptive procedure. In this operation, part of the stomach is resected (pylorus preserved) and the duodenum is cut just distal to the pylorus and reattached to the ileum, bypassing the duodenum and jejunum (i.e. digestive limb). The bypassed duodenum and jejunum (i.e. biliopancreatic limb) only passes bile and pancreatic juices. These loops converge at a common channel at the end of the small intestine and the contents then pass normally through the large intestine [9]. The jejunoileal bypass (JIB), bypasses most of the small intestine but is no longer performed because of a high incidence of severe complications [6].

\subsection{Procedures combining restriction and malabsorption}

In Roux-en-Y gastric bypass (RYGB), a small stomach pouch is created and connected to the middle small intestine, bypassing the majority of the stomach, the entire duodenum and part of the jejunum [6]. This is the most commonly performed weight loss operation in the US [6].

The distinction between restrictive and malabsorptive, although evident on a purely anatomical level, does not reflect the complexity of the endocrine and metabolic changes that occur in the gut and at the whole body level as a consequence of these various surgeries, as described below. In fact the distinction between restrictive and malabsorptive surgeries is rarely used.

\section{Integrated response to a meal: gastrointestinal physiology before and after bariatric surgery}

Bariatric surgery targets a number of different organ systems including the brain, stomach, small intestine, large intestine, liver, pancreas, adipose and muscle tissue (Fig. 2). Below, we have reviewed normal gastrointestinal physiology and the changes that occur after bariatric surgery.

\subsection{Cephalic phase}

The normal digestive-absorptive process starts with the cephalic phase, which results from the sight, smell, thought or taste of food. Many hormones are released as a result of the cephalic phase via vagal mechanisms, including ghrelin, insulin, pancreatic polypeptide (PP), and gastrin [10]. Ghrelin, an orexigenic hormone secreted by the stomach in anticipation of a meal, stimulates food intake when administered in humans [11]. Paradoxically, obese individuals have lower basal ghrelin levels versus lean persons [12], and ghrelin increases with diet-induced weight loss [13]. The beneficial effects of RYGB were initially thought to be mediated via suppressed ghrelin levels [13], however other studies have reported otherwise, including an increase after 1 year, as a function of the weight loss [14]. Gastrectomy (including partial gastrectomy with SG) leads to initially lower ghrelin levels [15], likely due to the removal of ghrelin-producing cells. However, levels recover after partial gastrectomy and evidence suggests that anastomosis to the duodenum versus the jejunum, leads to a better recovery of pregastrectomy ghrelin levels 
[16]. BPD leads to initial reduced fasting ghrelin levels, which return to preoperative levels months after the surgery [17]. Hence, although ghrelin levels decrease after surgeries that include gastrectomy, this effect is most often transient, and seems to depend on the energy balance status and the time-point after surgery investigated. Contrary to the initial hypothesis, it is unlikely that ghrelin plays a major role in the control of food intake after certain types of bariatric surgeries. Insulin release has also been shown to be under cephalic phase control [18] and the effects of RYGB on insulin secretion are discussed in detail in other sections of this review.

Two other gut peptides that play a role in the cephalic phase are PP and gastrin. PP, an anorexigenic hormone expressed in islets of the pancreas, is secreted in response to nutrient stimulation and requires intact signaling of the parasympathetic vagal nervous system [19]. PP has been generally reported as unchanged after RYGB and SG, however some studies have reported lower fasting levels post-RYGB [20-23]. Gastrin, primarily secreted from Gcells of the antrum in the stomach [24], aids in gastric acid secretion [25] and has been suggested to help facilitate insulin secretion via gastrin receptors in islets of the pancreas [24]. However, the few studies that have investigated gastrin levels after bariatric surgery have provided mixed results. Some studies show that gastrin levels are unchanged after RYGB [26] and duodenal-jejunal bypass (DJB) [27], however one study found that postprandial levels were lower 2 weeks post-RYGB [28]. Additionally, one rodent study suggests that gastrin is lower after RYGB and this may contribute to postoperative weight loss [29].

\subsection{Chewing and tasting}

RYGB may modulate chewing time, taste preference and food perception. After bariatric surgery, Godlewski et al. found that patients have increased chewing time and a greater number of chewing cycles for solid food, compared to preoperatively [30]. Furthermore, our group found an increased duration of nutrient ingestion after RYGB [31]. In contrast, Laurenius et al. showed that although mean meal duration was not changed, there was an increased number of meals and a reduction in meal size after RYGB [32], indicating that the rate of eating was lower. After RYGB and LAGB in humans, taste preference and food perception are modified [33]. After RYGB, these changes could be related to increased levels of satiety hormones peptide YY (PYY) and glucagon-like peptide (GLP)-1 [34], although this link has not been clearly demonstrated. Post-RYGB patients often report a change in taste and the loss of "cravings". This may be due to a selective reduction in neural responses to high calorie food, which is observed following RYGB [35]. The gustatory system and intestinal mucosa signal to the brain, which modulates the release of gastrointestinal hormones that have important roles on energy homeostasis, food intake and satiety [36]. These changes in eating behavior could contribute to the sustained weight loss after bariatric surgery [37].

\subsection{Gastric phase}

In the stomach, GE is regulated by gastric content, neural, and hormonal influences, and is altered after bariatric surgery. Horowitz et al. showed accelerated GE for liquids, but slower GE time for solids, after RYGB [38]. Furthermore, in patients after non-elective 
gastrectomy, Kotler et al. reported faster ITT and increased enteroglucagon levels in patients with greater weight loss compared to weight-stable patients [39]. This is supported by data from Morinigo et al., who showed accelerated GE and shortened ITT, as well as a positive correlation between GE and GLP-1, in subjects 6 weeks after RYGB [40]. Our group has recently shown accelerated GE 1 year after RYGB, using breath hydrogen analysis after Dxylose ingestion [41]. Accelerated GE may also lead to dumping syndrome, which was reported in $24 \%$ of subjects 1 year after RYGB [42].

Surgical manipulation of the antral pump has corresponding changes in GE. The partial antrum resection that is typically performed during SG may explain changes in GE. Braghetto et al. found that at 3 months postoperative, SG significantly accelerated GE after both solid and liquid meals versus controls [43]. Another group reported faster GE after a solid meal 6 and 24 months after SG [44]. However another study, which spared the antrum during SG showed no increase in GE after a semi-solid meal at 3 months [45]. Thus, the degree of antrum resection appears to have an impact on GE after SG. Accelerated GE may lead to rapid exposure of nutrients and secretions to the distal small intestine, which could enhance gut hormone release and may contribute to the increased weight loss and improved glucose homeostasis after surgery. This is exemplified by McLaughlin et al., who showed that administration of a meal directly into the bypassed gastric remnant of a post-RYGB patient, using a gastrostomy tube, reversed neuroglycopenia and hypersecretion of GLP-1 and insulin (versus oral intake which bypassed the gastric remnant and duodenum) [46].

\subsection{Intestinal phase and gut peptides}

The release of anorexigenic gut hormones GLP-1, PYY and oxyntomodulin (OXM) is enhanced after bariatric surgery.

3.4.1. GLP-1-GLP-1, secreted from L-cells in the distal small intestine and colon, stimulates insulin secretion, inhibits glucagon as well as gastrointestinal secretions and motility [47]. GLP-1 levels during an oral glucose or meal stimulation have been shown to be persistently increased after RYGB [14], BPD [48], and SG [49]. Conversely, predominantly restrictive procedures such as LAGB do not stimulate GLP-1 [14].

3.4.2. GLP-2 and GIP-GLP-2, released from intestinal L-cells after food intake, stimulates cellular proliferation and inhibits apoptosis of the ileal and bowel mucosa, increasing absorptive surface area. Levels of gastric inhibitory peptide (GIP), synthesized by $\mathrm{K}$-cells in the duodenal and jejunal mucosa, have been inconsistent after bariatric surgery however we have reported an increase after RYGB [50], while others have reported a decrease or an increase after JIB, RYGB and BPD [51].

3.4.3. PYY - PYY, secreted by mucosal L-cells in the small and large intestine, inhibits gastric, pancreatic and intestinal secretions. The effects on gastrointestinal motility and food intake, although reported, continue to be controversial [52,53]. Our group and others have reported increased postprandial PYY3-36 after RYGB [28,54], SG [49] and BPD [49], which could lead to enhanced satiety. 
3.4.4. OXM-OXM is an anorexigenic peptide co-secreted with PYY and GLP-1 in intestinal L-cells [55]. The administration of OXM reduces hunger, food intake and ghrelin levels as well as decreases gastric acid secretion, GE and duodenal motility [56,57]. Like the incretins and PYY3-36, postprandial OXM is increased 1-2 months after RYGB [58].

However, further studies are needed to understand the role of gut peptides in energy balance regulation after RYGB.

3.4.5. CCK-CCK, produced by intestinal I-cells, is a satiety hormone and inhibits GE and gastric motility [55,59]. CCK levels have been reported as increased after VBG, JIB, SG and RYGB [60-62].

\subsection{Absorptive phase}

Since the small intestine is the primary site of nutrient absorption, nutritional deficits are one of the predominant long-term complications of malabsorptive procedures, particularly after BPD [63]. Both RYGB and BPD are commonly associated with micronutrient deficiencies, which may include vitamins $\mathrm{A}, \mathrm{C}, \mathrm{D}, \mathrm{K}$, thiamine, folic acid and $\mathrm{B}_{12}$, and minerals including iron, selenium, zinc, and copper, with more severe deficiency after BPD [64]. There is little evidence for carbohydrate malabsorption after RYGB surgery [41,65], however evidence suggests fat malabsorption, with or without increased fecal fat excretion, does occur after RYGB [65-67].

\section{6. lleal brake}

Neuroendocrine mechanisms may mediate the effects of gut hormones on ingestive behavior. The duodenal and jejunal brakes are a negative feedback system, and a normal physiological response, that is activated when food contacts the duodenum and jejunum, leading to reduced hunger and food intake [68]. The ileal brake is a distal-to-proximal negative feedback, which influences jejunal motility, ITT, GE and pancreatic and biliary secretions [68]. Ileal brake activation results in delayed GE and increased ITT associated with a decrease in jejunal contraction, which may ultimately lead to prolonged satiety. PYY, GLP-1 and potentially OXM may mediate the ileal brake [68]; however, in the context of RYGB, the relative contribution of the ileal brake to the metabolic improvements observed is unknown.

\subsection{Possible postoperative gastrointestinal effects on type 2 diabetes}

Bariatric intervention results in effective long-term weight loss, which often results in diabetes remission. However, the rapid improvement in blood glucose within days and/or weeks after RYGB suggests weight-independent mechanisms in diabetes control. There are many potential theories proposed to explain this. The hindgut or incretin hypothesis proposes that the rapid nutrient delivery to the distal small intestine increases GLP-1 and PYY release, improving glucose metabolism [69-71]. The midgut hypothesis or intestinal/ hepatic regulation hypothesis proposes that the shunting of nutrients to the distal small intestine after RYGB enhances intestinal gluconeogenesis, which activates the hepato-portal glucose signaling system, which decreases food intake and suppresses hepatic glucose production (HGP), leading to improved glucose homeostasis [72]. The foregut hypothesis proposes that exclusion of nutrients from the proximal small intestine may suppress the 
secretion of unknown anti-incretin factors, leading to increased incretin release that improves glucose control [73]. However, this hypothesis has come into question as SG, which does not bypass the duodenum, also yields increased GLP-1, weight loss and improvements in glucose metabolism [20]. A recent elegant rodent study showed that after RYGB, the intestine increases its own glucose uptake and utilization, helping to regulate whole body glucose control in various models of diabetes [74]. The metabolic improvements after bariatric surgery warrant referral to these procedures as a "metabolic surgery" and type 2 diabetes to be labeled as an "intestinal disease" [75].

\subsection{Liver and bile acid phase}

After the aforementioned hormonal and enzymatic machinery acts on the chyme, absorbed nutrients are transported from the bloodstream to the liver. Glucose in the portal vein triggers hypothalamic metabolic centers, and results in decreased food intake and improved glucose homeostasis (via suppressed HGP and improved insulin sensitivity) [72]. In a rat study using a hyperinsulinemic euglycemic clamp, RYGB and SG significantly improved glucose metabolism and insulin sensitivity as a function of weight loss, and inhibited HGP and increased hepatic insulin sensitivity independent of weight loss [76]. These improvements are potentially related to the increased GLP-1 levels also observed after surgery, however further studies are required to understand this potential insulin-sensitizing effect on the liver. In humans, nondiabetic obese patients after RYGB showed improved hepatic insulin index, high levels of insulin and C-peptide and unchanged endogenous glucose production, compared to lean and obese control groups [77]. Furthermore, type 2 diabetes subjects one-month post-RYGB had improved HGP and hepatic insulin sensitivity index without an associated improvement in peripheral insulin sensitivity, demonstrating that RYGB can improve hepatic metabolism [78]. Additionally, obesity is often associated with nonalcoholic fatty liver disease, and strong evidence shows that bariatric surgery, including RYGB [79] and BPD [80], improves hepatic steatosis.

BAs are also implicated in the improvement in energy and glucose metabolism after RYGB [81]. It has been shown that fasting total serum BA and individual BA concentrations of taurodeoxycholic, glycocholic, glycochenodeoxychol and glycodeoxycholic acids were higher in patients with prior RYGB, compared to preoperative and postoperative BMImatched individuals. Furthermore, there was an inverse correlation between fasting total BA and postprandial glucose and a positive correlation between fasting total BA and peak GLP-1 levels [82]. Another study showed a two-fold increase in fasting total BAs and approximately 3-fold increase in deoxycholic acid 1 year after RYGB [83]. Furthermore, Pournaras et al. recently showed that fasting total serum BA are increased in patients days after RYGB, but not after LAGB. It was recently shown that the suppression of postprandial conjugated BA levels, observed in obese humans, was restored after RYGB [84]. Studies in rats showed that bile delivered to the ileum, as opposed to the duodenum in intact rats, led to increased satiety hormone levels and weight loss, suggesting that the delivery of BA to the ileum in RYGB could be partly responsible for the metabolic effects observed [85]. Some studies also report an alteration in BA metabolism and its enterohepatic circulation after JIB $[86,87]$. BA have been shown to inhibit weight and adiposity gain in mice via increased 
thyroid-hormone mediated energy expenditure in brown adipose tissue and it is possible that this mechanism could be relevant to post-RYGB patients [88].

\subsection{Large intestine and microbiota phase}

Normally, the large intestine predominately absorbs water and electrolytes [89]. However, in patients with small bowel resection, the colon adapts and may act as a digestive organ, using bacterial fermentation to digest malabsorbed carbohydrates and some proteins, with subsequent absorption and some contribution to the energy supply [90]. In the large intestine there is an enormous population and variety of microbes, which perform many metabolic functions including digestion of indigestible carbohydrates, synthesis of vitamins and amino acids, and biotransformation of BA [91]. Evidence from rats and humans shows that gut microflora are different in lean versus obese subjects [92,93], and individuals with diabetes have reduced proportions of Firmicutes and Clostridia [94]. These differences may carry significant metabolic relevance and could play a role in weight loss and improvement in glucose metabolism after bariatric surgery. Studies investigating microbiota in subjects after RYGB found substantial differences in the intestinal environment post-RYGB $[95,96]$.

Zhang et al. found that Firmicutes microflora were predominant in obese and normal-weight patients, but were decreased after RYGB. Individuals after RYGB also had a large population of Gammaproteobacteria, which were not found in subjects prior to surgery. It is possible that these altered microbiota populations could have a metabolic impact [95]. It has also been shown that RYGB patients supplemented with probiotics had increased percent excess weight loss at 6 and 12 weeks after surgery [97]. The impact of microbiota on outcomes after RYGB and obesity and metabolism is not fully understood and deserves further exploration.

\subsection{Trophic changes of the small and large intestine}

Bariatric surgery can result in potential trophic changes of the large and small intestine. Studies in rats have shown compensatory hypertrophy of the remaining bowel after JIB [98]. Furthermore, the low incidence of nutrient malabsorption after bariatric surgery (including both BPD and RYGB) may be due to GLP-2-mediated small intestinal hypertrophy, as GLP-2 promotes cellular division and inhibits apoptosis of the mucosa of the small intestine [99]. Additionally, increased post-surgical levels of PYY have been correlated with postoperative gut hypertrophy after BPD and RYGB [100].

\section{Conclusion}

Most bariatric surgeries result in sustained weight loss and improvement in associated comorbidities. Each type of bariatric procedure affects the morphology, endocrine function and physiology of the digestive system in specific ways. Although a number of the beneficial metabolic effects of bariatric surgery can be attributed to weight loss, the rapid changes in a majority of gut hormones, which occur rapidly after RYGB, associated with an improvement in comorbidities, suggests that the anatomic and physiologic changes after surgery are also important [100]. Further research is required to determine which bariatric procedure provides the greatest benefit while minimizing untoward side effects and complications, and ongoing research in this field will help elucidate the role of the 
gastrointestinal tract in the pathophysiology of obesity, type 2 diabetes and other metabolic comorbidities.

\section{Supplementary Material}

Refer to Web version on PubMed Central for supplementary material.

\section{Acknowledgements}

We would like to thank Walter Pories, for permission to use his previously published figure.

Guarantor of the article: B. Laferrère.

Specific author contributions: I. Quercia wrote the paper and R. Dutia, D.P. Kotler, S. Belsley and B. Laferrère provided edits. The final manuscript was approved by all authors.

Financial support: None.

\section{Appendix A. Supplementary data}

Supplementary data associated with this article can be found, in the online version, at http:// dx.doi.org/10.1016/j.diabet.2013.11.003.

\section{References}

1. Flegal KM, Carroll MD, Kit BK, Ogden CL. Prevalence of obesity and trends in the distribution of body mass index among US adults, 1999-2010. JAMA. 2012; 307:491-497. [PubMed: 22253363]

2. Haslam DW, James WP. Obesity. Lancet. 2005; 366(9492):1197-1209. [PubMed: 16198769]

3. NIH Technology Assessment Conference Panel. Methods for voluntary weight loss and control. Ann Intern Med. 1992; 116:942-949. [PubMed: 1580453]

4. Consensus Development Conference Panel. NIH conference. Gastrointestinal surgery for severe obesity. Ann Intern Med. 1991; 115:956-961. [PubMed: 1952493]

5. Foreman, C. Letter approving LAP-BAND ${ }^{\mathrm{TM}}$ Adjustable Gastric Banding System. Services DoHaH. , editor. Silver Spring, MD: Center for Devices and Radiological Health of the Food and Drug Administration; 2011.

6. Pories WJ. Bariatric surgery: risks and rewards. J Clin Endocrinol Metab. 2008; 93 Suppl 1(11):S89-S96. [PubMed: 18987275]

7. Stimac D, Majanovic SK. Endoscopic approaches to obesity. Dig Dis. 2012; 30:187-195. [PubMed: 22722437]

8. Khazzaka A, Sarkis R. Fundoplication combined with mediogastric plication. Surg Obes Relat Dis. 2013; 9:398-403. [PubMed: 21978753]

9. Crookes PF. Surgical treatment of morbid obesity. Annu Rev Med. 2006; 57:243-264. [PubMed: 16409148]

10. Power ML, Schulkin J. Anticipatory physiological regulation in feeding biology: cephalic phase responses. Appetite. 2008; 50:194-206. [PubMed: 18045735]

11. Cummings DE, Purnell JQ, Frayo RS, Schmidova K, Wisse BE, Weigle DS. A preprandial rise in plasma ghrelin levels suggests a role in meal initiation in humans. Diabetes. 2001; 50(8):17141719. [PubMed PMID: 11473029]. [PubMed: 11473029]

12. Tschop M, Weyer C, Tataranni PA, Devanarayan V, Ravussin E, Heiman ML. Circulating ghrelin levels are decreased in human obesity. Diabetes. 2001; 50:707-709. [PubMed: 11289032]

13. Cummings DE, Weigle DS, Frayo RS, Breen PA, Ma MK, Dellinger EP, et al. Plasma ghrelin levels after diet-induced weight loss or gastric bypass surgery. N Engl J Med. 2002; 346:16231630. [PubMed: 12023994] 
14. Bose M, Machineni S, Olivan B, Teixeira J, McGinty JJ, Bawa B, et al. Superior appetite hormone profile after equivalent weight loss by gastric bypass compared to gastric banding. Obesity. 2010; 18:1085-1091. [PubMed: 20057364]

15. Karamanakos SN, Vagenas K, Kalfarentzos F, Alexandrides TK. Weight loss, appetite suppression, and changes in fasting and postprandial ghrelin and peptide YY levels after Roux-enY gastric bypass and sleeve gastrectomy: a prospective, double blind study. Ann Surg. 2008; 247:401-407. [PubMed: 18376181]

16. Wang HT, Lu QC, Wang Q, Wang RC, Zhang Y, Chen HL, et al. Role of the duodenum in regulation of plasma ghrelin levels and body mass index after subtotal gastrectomy. World $\mathrm{J}$ Gastroenterol. 2008; 14:2425-2429. [PubMed: 18416474]

17. Adami GF, Cordera R, Marinari G, Lamerini G, Andraghetti G, Scopinaro N. Plasma ghrelin concentratin in the short-term following biliopancreatic diversion. Obes Surg. 2003; 13:889-892. [PubMed: 14738676]

18. Teff K. Nutritional implications of the cephalic phase reflexes: endocrine responses. Appetite. 2000; 34:206-213. [PubMed: 10744911]

19. Kojima S, Ueno N, Asakawa A, Sagiyama K, Naruo T, Mizuno S, et al. A role for pancreatic polypeptide in feeding and body weight regulation. Peptides. 2007; 28:459-463. [PubMed: 17207558]

20. Ramon JM, Salvans S, Crous X, Puig S, Goday A, Benaiges D, et al. Effect of Roux-en-Y gastric bypass vs sleeve gastrectomy on glucose and gut hormones: a prospective randomised trial. $\mathrm{J}$ Gastrointest Surg. 2012; 16:1116-1122. [PubMed: 22402955]

21. Holdstock C, Zethelius B, Sundbom M, Karlsson FA, Eden Engstrom B. Postprandial changes in gut regulatory peptides in gastric bypass patients. Int J Obes. 2008; 32:1640-1646.

22. Swarbrick MM, Stanhope KL, Austrheim-Smith IT, Van Loan MD, Ali MR, Wolfe BM, et al. Longitudinal changes in pancreatic and adipocyte hormones following Roux-en-Y gastric bypass surgery. Diabetologia. 2008; 51:1901-1911. [PubMed: 18704364]

23. Schrumpf E, Linnestad P, Nygaard K, Giercksky KE, Fausa O. Pancreatic polypeptide secretion before and after gastric bypass surgery for morbid obesity. Scand J Gastroenterol. 1981; 16:10091014. [PubMed: 7038840]

24. Rehfeld JF. Incretin physiology beyond glucagon-like peptide 1 and glucose-dependent insulinotropic polypeptide: cholecystokinin and gastrin peptides. Acta Physiol. 2011; 201:405411.

25. Lloyd KC. Gut hormones in gastric function. Bailliere's Clin Endocrinol Metab. 1994; 8:111-136. [PubMed: 7907860]

26. Schrumpf E, Giercksky KE, Nygaard K, Fausa O. Gastrin secretion before and after gastric bypass surgery for morbid obesity. Scand J Gastroenterol. 1981; 16:721-725. [PubMed: 7034160]

27. Ferzli GS, Dominique E, Ciaglia M, Bluth MH, Gonzalez A, Fingerhut A. Clinical improvement after duodenojejunal bypass for non-obese type 2 diabetes despite minimal improvement in glycemic homeostasis. World J Surg. 2009; 33:972-979. [PubMed: 19288284]

28. Jacobsen SH, Olesen SC, Dirksen C, Jorgensen NB, Bojsen-Moller KN, Kielgast U, et al. Changes in gastrointestinal hormone responses, insulin sensitivity, and beta-cell function within 2 weeks after gastric bypass in nondiabetic subjects. Obes Surg. 2012; 22:1084-1096. [PubMed: 22359255]

29. Stenstrom B, Zhao CM, Tommeras K, Arum CJ, Chen D. Is gastrin partially responsible for body weight reduction after gastric bypass? Eur Surg Res. 2006; 38:94-101. [PubMed: 16645284]

30. Godlewski AE, Veyrune JL, Nicolas E, Ciangura CA, Chaussain CC, Czernichow S, et al. Effect of dental status on changes in mastication in patients with obesity following bariatric surgery. PloS One. 2011; 6:e22324. [PubMed: 21799822]

31. Laferrère B. Gut feelings about diabetes. Endocrinol Nutr. 2012; 59:254-260. [PubMed: 22386248]

32. Laurenius A, Larsson I, Bueter M, Melanson KJ, Bosaeus I, Forslund HB, et al. Changes in eating behaviour and meal pattern following Roux-en-Y gastric bypass. Int J Obes. 2012; 36:348-355. 
33. Tichansky DS, Boughter JD Jr, Madan AK. Taste change after laparoscopic Roux-en-Y gastric bypass and laparoscopic adjustable gastric banding. Surg Obes Relat Dis. 2006; 2:440-444. [PubMed: 16925376]

34. Bueter M, Miras AD, Chichger H, Fenske W, Ghatei MA, Bloom SR, et al. Alterations of sucrose preference after Roux-en-Y gastric bypass. Physiol Behav. 2011; 104:709-721. [PubMed: 21827777]

35. Ochner CN, Kwok Y, Conceicao E, Pantazatos SP, Puma LM, Carnell S, et al. Selective reduction in neural responses to high calorie foods following gastric bypass surgery. Ann Surg. 2011; 253:502-507. [PubMed: 21169809]

36. Oliveira-Maia AJ, Roberts CD, Simon SA, Nicolelis MA. Gustatory and reward brain circuits in the control of food intake. Adv Tech Stand Neurosurg. 2011; 36:31-59. [PubMed: 21197607]

37. Kokkinos A, le Roux CW, Alexiadou K, Tentolouris N, Vincent RP, Kyriaki D, et al. Eating slowly increases the postprandial response of the anorexigenic gut hormones, peptide YY and glucagon-like peptide-1. J Clin Endocrinol Metab. 2010; 95:333-337. [PubMed: 19875483]

38. Horowitz M, Cook DJ, Collins PJ, Harding PE, Hooper MJ, Walsh JF, et al. Measurement of gastric emptying after gastric bypass surgery using radionuclides. Br J Surg. 1982; 69:655-657. [PubMed: 7127049]

39. Kotler DP, Sherman D, Bloom SR, Holt PR. Malnutrition after gastric surgery. Association with exaggerated distal intestinal hormone release. Dig Dis Sci. 1985; 30:193-199. [PubMed: 3971831]

40. Morinigo R, Moize V, Musri M, Lacy AM, Navarro S, Marin JL, et al. Glucagon-like peptide-1, peptide YY, hunger, and satiety after gastric bypass surgery in morbidly obese subjects. J Clin Endocrinol Metab. 2006; 91:1735-1740. [PubMed: 16478824]

41. Wang G, Agenor K, Pizot J, Kotler DP, Harel Y, Van Der Schueren BJ, et al. Accelerated gastric emptying but no carbohydrate malabsorption 1 year after gastric bypass surgery (GBP). Obes Surg. 2012; 22:1263-1267. [PubMed: 22527599]

42. Padoin AV, Galvao Neto M, Moretto M, Barancelli F, Schroer CE, Mottin CC. Obese patients with type 2 diabetes submitted to banded gastric bypass: greater incidence of dumping syndrome. Obes Surg. 2009; 19:1481-1484. [PubMed: 19714385]

43. Braghetto I, Davanzo C, Korn O, Csendes A, Valladares H, Herrera E, et al. Scintigraphic evaluation of gastric emptying in obese patients submitted to sleeve gastrectomy compared to normal subjects. Obes Surg. 2009; 19:1515-1521. [PubMed: 19714384]

44. Melissas J, Daskalakis M, Koukouraki S, Askoxylakis I, Metaxari M, Dimitriadis E, et al. Sleeve gastrectomy-a "food limiting" operation. Obes Surg. 2008; 18:1251-1256. [PubMed: 18663545]

45. Bernstine H, Tzioni-Yehoshua R, Groshar D, Beglaibter N, Shikora S, Rosenthal RJ, et al. Gastric emptying is not affected by sleeve gastrectomy - scintigraphic evaluation of gastric emptying after sleeve gastrectomy without removal of the gastric antrum. Obes Surg. 2009; 19:293-298. [PubMed: 19089519]

46. McLaughlin T, Peck M, Holst J, Deacon C. Reversible hyperinsulinemic hypoglycemia after gastric bypass: a consequence of altered nutrient delivery. J Clin Endocrinol Metab. 2010; 95:1851-1855. [PubMed: 20133462]

47. Holst JJ. On the physiology of GIP and GLP-1. Horm Metab Res. 2004; 36:747-754. [PubMed: 15655703]

48. Borg CM, le Roux CW, Ghatei MA, Bloom SR, Patel AG. Biliopancreatic diversion in rats is associated with intestinal hypertrophy and with increased GLP-1, GLP-2 and PYY levels. Obes Surg. 2007; 17:1193-1198. [PubMed: 18074494]

49. Tsoli M, Chronaiou A, Kehagias I, Kalfarentzos F, Alexandrides TK. Hormone changes and diabetes resolution after biliopancreatic diversion and laparoscopic sleeve gastrectomy: a comparative prospective study. Surg Obes Relat Dis. 2013; 9:667-677. [PubMed: 23466015]

50. Bose M, Teixeira J, Olivan B, Bawa B, Arias S, Machineni S, et al. Weight loss and incretin responsiveness improve glucose control independently after gastric bypass surgery. J Diabetes. 2010; 2:47-55. [PubMed: 20676394]

51. Rao RS, Kini S. GIP and bariatric surgery. Obes Surg. 2011; 21:244-252. [PubMed: 21082290]

52. De Silva A, Bloom SR. Gut hormones and appetite control: a focus on PYY and GLP-1 as therapeutic targets in obesity. Gut Liver. 2012; 6:10-20. [PubMed: 22375166] 
53. Boggiano MM, Chandler PC, Oswald KD, Rodgers RJ, Blundell JE, Ishii Y, et al. PYY3-36 as an anti-obesity drug target. Obes Rev. 2005; 6:307-322. [PubMed: 16246216]

54. Olivan B, Teixeira J, Bose M, Bawa B, Chang T, Summe H, et al. Effect of weight loss by diet or gastric bypass surgery on peptide YY3-36 levels. Ann Surg. 2009; 249:948-953. [PubMed: 19474685]

55. Vincent RP, le Roux CW. Changes in gut hormones after bariatric surgery. Clin Endocrinol. 2008; 69:173-179.

56. Cohen MA, Ellis SM, Le Roux CW, Batterham RL, Park A, Patterson M, et al. Oxyntomodulin suppresses appetite and reduces food intake in humans. J Clin Endocrinol Metab. 2003; 88:46964701. [PubMed: 14557443]

57. Schjoldager B, Mortensen PE, Myhre J, Christiansen J, Holst JJ. Oxyntomodulin from distal gut. Role in regulation of gastric and pancreatic functions. Dig Dis Sci. 1989; 34:1411-1419. [PubMed: 2670487]

58. Laferrère B, Swerdlow N, Bawa B, Arias S, Bose M, Olivan B, et al. Rise of oxyntomodulin in response to oral glucose after gastric bypass surgery in patients with type 2 diabetes. $\mathrm{J}$ Clin Endocrinol Metab. 2010; 95:4072-4076. [PubMed: 20501690]

59. Neary MT, Batterham RL. Gut hormones: implications for the treatment of obesity. Pharmacol Ther. 2009; 124:44-56. [PubMed: 19560488]

60. Foschi D, Corsi F, Pisoni L, Vago T, Bevilacqua M, Asti E, et al. Plasma cholecystokinin levels after vertical banded gastroplasty: effects of an acidified meal. Obes Surg. 2004; 14:644-647. [PubMed: 15186632]

61. Naslund E, Gryback P, Hellstrom PM, Jacobsson H, Holst JJ, Theodorsson E, et al. Gastrointestinal hormones and gastric emptying 20 years after jejunoileal bypass for massive obesity. Int J Obes Relat Metab Disord. 1997; 21:387-392. [PubMed: 9152741]

62. Peterli R, Steinert RE, Woelnerhanssen B, Peters T, Christoffel-Courtin C, Gass M, et al. Metabolic and hormonal changes after laparoscopic Roux-en-Y gastric bypass and sleeve gastrectomy: a randomized, prospective trial. Obes Surg. 2012; 22:740-748. [PubMed: 22354457]

63. Koch TR, Finelli FC. Postoperative metabolic and nutritional complications of bariatric surgery. Gastroenterol Clin N Am. 2010; 39:109-124.

64. Shankar P, Boylan M, Sriram K. Micronutrient deficiencies after bariatric surgery. Nutrition. 2010; 26:1031-1037. [PubMed: 20363593]

65. Odstrcil EA, Martinez JG, Santa Ana CA, Xue B, Schneider RE, Steffer KJ, et al. The contribution of malabsorption to the reduction in net energy absorption after long-limb Roux-en-Y gastric bypass. Am J Clin Nutr. 2010; 92:704-713. [PubMed: 20739420]

66. Kumar R, Lieske JC, Collazo-Clavell ML, Sarr MG, Olson ER, Vrtiska TJ, et al. Fat malabsorption and increased intestinal oxalate absorption are common after Roux-en-Y gastric bypass surgery. Surgery. 2011; 149:654-661. [PubMed: 21295813]

67. Stemmer K, Bielohuby M, Grayson BE, Begg DP, Chambers AP, Neff C, et al. Roux-en-Y gastric bypass surgery but not vertical sleeve gastrectomy decreases bone mass in male rats. Endocrinology. 2013; 154:2015-2024. [PubMed: 23554454]

68. Maljaars PW, Peters HP, Mela DJ, Masclee AA. Ileal brake: a sensible food target for appetite control. A review. Physiol Behav. 2008; 95:271-281. [PubMed: 18692080]

69. Strader AD, Vahl TP, Jandacek RJ, Woods SC, D'Alessio DA, Seeley RJ. Weight loss through ileal transposition is accompanied by increased ileal hormone secretion and synthesis in rats. Am J Physiol Endocrinol Metab. 2005; 288:E447-E453. [PubMed: 15454396]

70. Cummings BP, Strader AD, Stanhope KL, Graham JL, Lee J, Raybould HE, et al. Ileal interposition surgery improves glucose and lipid metabolism and delays diabetes onset in the UCD-T2DM rat. Gastroenterology. 2010; 138:2437-2446. [46 e1]. [PubMed: 20226188]

71. Patriti A, Facchiano E, Annetti C, Aisa MC, Galli F, Fanelli C, et al. Early improvement of glucose tolerance after ileal transposition in a non-obese type 2 diabetes rat model. Obes Surg. 2005; 15:1258-1264. [PubMed: 16259883]

72. Mithieux G. A novel function of intestinal gluconeogenesis: central signaling in glucose and energy homeostasis. Nutrition. 2009; 25:881-884. [PubMed: 19647621] 
73. Rubino F, Marescaux J. Effect of duodenal-jejunal exclusion in a non-obese animal model of type 2 diabetes: a new perspective for an old disease. Ann Surg. 2004; 239:1-11. [PubMed: 14685093]

74. Saeidi N, Meoli L, Nestoridi E, Gupta NK, Kvas S, Kucharczyk J, et al. Reprogramming of intestinal glucose metabolism and glycemic control in rats after gastric bypass. Science. 2013; 341:406-410. [PubMed: 23888041]

75. Pories WJ, Mehaffey JH, Staton KM. The surgical treatment of type two diabetes mellitus. Surg Clin N Am. 2011; 91:821-836. [viii]. [PubMed: 21787970]

76. Chambers AP, Jessen L, Ryan KK, Sisley S, Wilson-Perez HE, Stefater MA, et al. Weightindependent changes in blood glucose homeostasis after gastric bypass or vertical sleeve gastrectomy in rats. Gastroenterology. 2011; 141:950-958. [PubMed: 21699789]

77. Promintzer-Schifferl M, Prager G, Anderwald C, Mandl M, Esterbauer H, Shakeri-Leidenmuhler $\mathrm{S}$, et al. Effects of gastric bypass surgery on insulin resistance and insulin secretion in nondiabetic obese patients. Obesity. 2011; 19:1420-1426. [PubMed: 21494227]

78. Dunn JP, Abumrad NN, Breitman I, Marks-Shulman PA, Flynn CR, Jabbour K, et al. Hepatic and peripheral insulin sensitivity and diabetes remission at 1 month after Roux-en-Y gastric bypass surgery in patients randomized to omentectomy. Diabetes Care. 2012; 35:137-142. [PubMed: 22040841]

79. Klein S, Mittendorfer B, Eagon JC, Patterson B, Grant L, Feirt N, et al. Gastric bypass surgery improves metabolic and hepatic abnormalities associated with nonalcoholic fatty liver disease. Gastroenterology. 2006; 130:1564-1572. [PubMed: 16697719]

80. Kral JG, Thung SN, Biron S, Hould FS, Lebel S, Marceau S, et al. Effects of surgical treatment of the metabolic syndrome on liver fibrosis and cirrhosis. Surgery. 2004; 135:48-58. [PubMed: 14694300]

81. Patti ME, Houten SM, Bianco AC, Bernier R, Larsen PR, Holst JJ, et al. Serum bile acids are higher in humans with prior gastric bypass: potential contribution to improved glucose and lipid metabolism. Obesity. 2009; 17:1671-1677. [PubMed: 19360006]

82. Houten SM, Watanabe M, Auwerx J. Endocrine functions of bile acids. EMBO J. 2006; 25:14191425. [PubMed PMID: 16541101]. [PubMed: 16541101]

83. Simonen M, Dali-Youcef N, Kaminska D, Venesmaa S, Kakela P, Paakkonen M, et al. Conjugated bile acids associate with altered rates of glucose and lipid oxidation after Roux-en-Y gastric bypass. Obes Surg. 2012; 22(9):1473-1480. [PubMed PMID: 22638681]. [PubMed: 22638681]

84. Ahmad NN, Pfalzer A, Kaplan LM. Roux-en-Y gastric bypass normalizes the blunted postprandial bile acid excursion associated with obesity. Int J Obes. 2013 [doi:10.1038].

85. Pournaras DJ, Glicksman C, Vincent RP, Kuganolipava S, Alaghband-Zadeh J, Mahon D, et al. The role of bile after Roux-en-Y gastric bypass in promoting weight loss and improving glycaemic control. Endocrinology. 2012; 153:3613-3619. [PubMed: 22673227]

86. Bruusgaard A, Sorensen TI, Justesen T, Krag E. Bile acid metabolism after jejunoileal bypass operation for obesity. Scand J Gastroenterol. 1976; 11:833-838. [PubMed: 1006159]

87. Fromm H, Sarva RP, Ravitch MM, McJunkin B, Farivar S, Amin P. Effects of jejunoileal bypass on the enterohepatic circulation of bile acids, bacterial flora in the upper small intestine, and absorption of vitamin B12. Metab Clin Exp. 1983; 32:1133-1141. [PubMed: 6645962]

88. Watanabe M, Houten SM, Mataki C, Christoffolete MA, Kim BW, Sato H, et al. Bile acids induce energy expenditure by promoting intracellular thyroid hormone activation. Nature. 2006; 439:484489. [PubMed: 16400329]

89. Bharucha AE. Lower gastrointestinal functions. Neurogastroenterol Motil. 2008; 20(Suppl. 1): 103-113. [PubMed: 18402647]

90. Nordgaard I, Hansen BS, Mortensen PB. Importance of colonic support for energy absorption as small bowel failure proceeds. Am J Clin Nutr. 1996; 64:222-231. [PubMed: 8694024]

91. Salminen S, Bouley C, Boutron-Ruault MC, Cummings JH, Franck A, Gibson GR, et al. Functional food science and gastrointestinal physiology and function. Br J Nutr. 1998; 80(Suppl 1):S147-S171. [PubMed: 9849357]

92. Ley RE, Backhed F, Turnbaugh P, Lozupone CA, Knight RD, Gordon JI. Obesity alters gut microbial ecology. Proc Natl Acad Sci U S A. 2005; 102:11070-11075. [PubMed: 16033867] 
93. Ley RE, Turnbaugh PJ, Klein S, Gordon JI. Microbial ecology: human gut microbes associated with obesity. Nature. 2006; 444:1022-1023. [PubMed: 17183309]

94. Larsen N, Vogensen FK, van den Berg FW, Nielsen DS, Andreasen AS, Pedersen BK, et al. Gut microbiota in human adults with type 2 diabetes differs from nondiabetic adults. PloS One. 2010; 5:e9085. [PubMed: 20140211]

95. Zhang H, DiBaise JK, Zuccolo A, Kudrna D, Braidotti M, Yu Y, et al. Human gut microbiota in obesity and after gastric bypass. Proc Natl Acad Sci U S A. 2009; 106:2365-2370. [PubMed: 19164560]

96. Furet JP, Kong LC, Tap J, Poitou C, Basdevant A, Bouillot JL, et al. Differential adaptation of human gut microbiota to bariatric surgery-induced weight loss: links with metabolic and low-grade inflammation markers. Diabetes. 2010; 59:3049-3057. [PubMed: 20876719]

97. Woodard GA, Encarnacion B, Downey JR, Peraza J, Chong K, Hernandez-Boussard T, et al. Probiotics improve outcomes after Roux-en-Y gastric bypass surgery: a prospective randomized trial. J Gastrointest Surg. 2009; 13:1198-1204. [PubMed: 19381735]

98. Olubuyide IO, Williamson RC, Bristol JB, Read AE. Goblet cell hyperplasia is a feature of the adaptive response to jejunoileal bypass in rats. Gut. 1984; 25:62-68. [PubMed: 6690374]

99. le Roux CW, Borg C, Wallis K, Vincent RP, Bueter M, Goodlad R, et al. Gut hypertrophy after gastric bypass is associated with increased glucagon-like peptide 2 and intestinal crypt cell proliferation. Ann Surg. 2010; 252:50-56. [PubMed: 20562614]

100. le Roux CW, Aylwin SJ, Batterham RL, Borg CM, Coyle F, Prasad V, et al. Gut hormone profiles following bariatric surgery favor an anorectic state, facilitate weight loss, and improve metabolic parameters. Ann Surg. 2006; 243:108-114. [PubMed: 16371744]

101. Pories, W. Diagram of surgical options. 2009. [Online]. Online; [cited 2013]. Available from: http://win.niddk.nih.gov/publications/gastric.htm 



Fig. 1.

Types of bariatric surgery.

Obtained from Pories [101] with permission. 
BRAN

Alterations in the gut-brain axis $\rightarrow$ change taste and macromutrient selection, tfood intake, $\uparrow$ energy expenditure

\section{STOHACH}

Decreased relaxation phase $\rightarrow$ faster gastric emphying rate Separation or removal of fundus $\rightarrow$ changes in secretion of gastrichormone ghrelin

SMALINTESTINE Bypass of the duodenum and/or jejum $\rightarrow$ Faster intestinal transit time and increases release of gut peptides (GLP-1, GIP, PYY

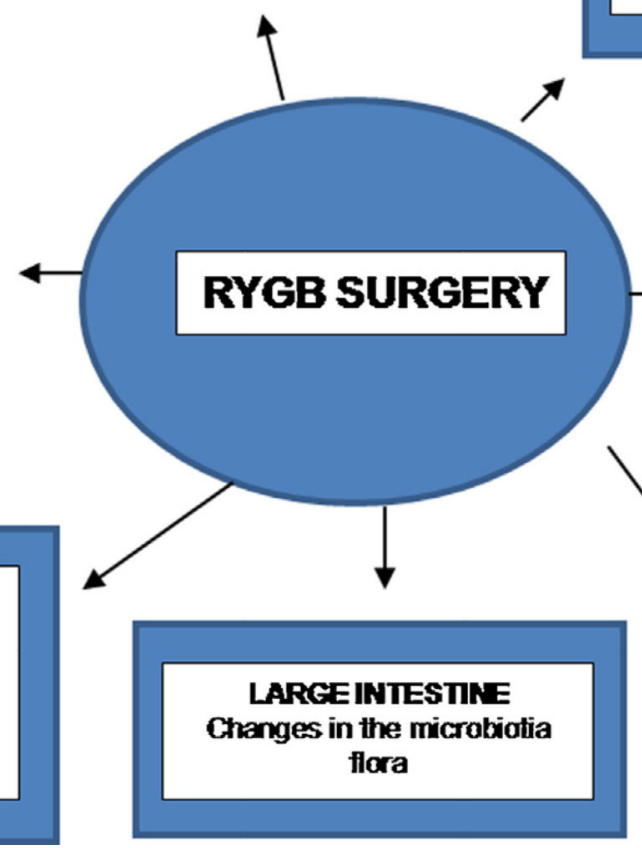

ADIPOSE TISSUE

A reduction in adpose tissue mass and a change in distribution $\rightarrow$ improvement in insulin sensitivity

Fig. 2.

Potential gastrointestinal changes after Roux-en-Y gastric bypass. 